\title{
ANALISIS PROSES BERPIKIR LATERAL PESERTA DIDIK DALAM MENYELESAIKAN SOAL OPEN ENDED DITINJAU DARI GAYA BERPIKIR ACAK KONKRET DAN ACAK ABSTRAK
}

\section{LATERAL THINKING PROCESS ANALYSIS OF STUDENTS IN SOLVING OPEN ENDED PROBLEMS FROM CONCRETE RANDOM AND RANDOM THINKING STYLE ABSTRACT}

\author{
Devin Rosmayanthi a , Nani Ratnaningsih ${ }^{\mathrm{b}}$, Supratman ${ }^{\mathrm{c}}$ \\ ${ }^{a}$ Program Studi Magister Pendidikan Matematika, Pascasarjana UNSIL \\ J1. Siliwangi Nomor 24 Tasikmalaya 46115, devin.rosmayanthi2015@gmail.com \\ b Program Studi Magister Pendidikan Matematika, Pascasarjana UNSIL \\ Jl. Siliwangi Nomor 24 Tasikmalaya 46115, naniratnaningsih@unsil.ac.id \\ ${ }^{c}$ Program Studi Magister Pendidikan Matematika, Pascasarjana UNSIL \\ Jl. Siliwangi Nomor 24 Tasikmalaya 46115, supratman181162@ gmail.com
}

\begin{abstract}
ABSTRAK
Tujuan penelitian ini adalah untuk mendeskripsikan proses berpikir lateral peserta didik dalam menyelesaikan soal open ended ditinjau dari gaya berpikir acak konkret dan gaya berpikir acak abstrak. Penelitian yang dilakukan merupakan penelitian kualitatif dengan metode eksploratif. Instrumen penelitian yang digunakan adalah soal open ended, angket gaya berpikir Gregorc dan wawancara. Subjek penelitian terdiri dari empat orang peserta didik dari kelas XI SMK Karya Nasional Sindangkasih Ciamis dengan dua subjek gaya berpikir Acak Konkret (AK) dan dua subjek gaya berpikir Acak Abstrak (AA). Hasil penelitian menunjukkan bahwa: 1) Proses berpikir peserta didik dengan gaya berpikir Acak Konkret (AK) memenuhi semua aspek berpikir lateral. 2) Proses berpikir peserta didik dengan gaya berpikir Acak Abstrak (AA) memenuhi semua aspek berpikir lateral.
\end{abstract}

Kata Kunci : Proses Berpikir Lateral, Soal Open Ended, Acak Konkret, Acak Abstrak

\section{ABSTRACT}

The purpose of this study was to describe the lateral thinking process of students in solving open-ended questions in terms of concrete random thinking styles and abstract random thinking styles. This research is a qualitative research with exploratory method. The research instruments used were open ended questions, Gregorc's thinking style questionnaire and interviews. The research subjects consisted of four students from class XI of SMK Karya Nasional Sindangkasih Ciamis with two subjects of Concrete Random Thinking (AK) and two subjects of Abstract Randomized Thinking (AA). The results showed that: 1) The thinking process of students with Concrete Random Thinking (AK) fulfilled all aspects of lateral thinking. 2) The thinking process of students with the Abstract Randomized Thinking style (AA) fulfills all aspects of lateral thinking.

Keywords: Lateral Thinking Process, Open Ended Problem, Concrate Random, Abstract Random 


\section{Pendahuluan}

Setiap orang memiliki berbagai macam aktivitas ataupun kegiatan yang menunjang kebutuhan hidupnya, salah satunya adalah berpikir. Dengan berpikir manusia bisa mendapatkan informasi, memproses informasi, mengingat, dan menggunakannya di dalam kehidupan seharihari. Wardhani, Subanji, and Dwiyana (2016) menyatakan bahwa proses berpikir merupakan aktivitas mental yang dilakukan peserta didik yang dimulai dari penerimaan, pengolahan, penyimpanan, dan pengambilan kembali suatu informasi dalam rangka mengambil suatu keputusan saat memecahkan masalah. Proses berpikir setiap peserta didik itu berbeda-beda. Dalam proses pembelajaran matematika, proses berpikir sangat diperlukan untuk memahami setiap konsep matematika yang dipelajari serta mampu menggunakan konsep tersebut secara tepat. Penting sekali bagi seorang guru untuk mengetahui proses berpikir setiap peserta didik dalam menyelesaikan masalah matematika (Nurjanah, Hidayanto \& Rahardjo, 2019). Dengan mengetahui proses berpikir peserta didiknya, seorang guru dapat mendiagnosis dan menelusuri letak kesulitan peserta didik dalam menyelesaikan suatu masalah (Muliawati, 2017), sehingga kesulitan peserta didik dapat sedikit teratasi dengan adanya bantuan dari guru. Namun selama ini proses berpikir tersebut masih kurang diperhatikan.

Dalam mempelajari matematika ada beberapa kemampuan berpikir yang harus dimiliki oleh peserta didik agar mereka bisa menyelesaikan setiap permasalahan secara efektif dan efisien. Suryadi (dalam Wendayani, Ratnaningsih and Muhtadi, 2019) mengemukakan bahwa pengembangan berpikir matematika tingkat tinggi memerlukan perhatian yang lebih karena selama ini umumnya pembelajaran matematika masih berfokus pada berpikir matematika tingkat rendah yang bersifat prosedural. Salah satu berpikir matematika tingkat tinggi yang diperlukan oleh peserta didik saat ini adalah berpikir lateral karena dengan berpikir lateral seseorang bisa memandang dan menyelesaikan masalah dari berbagai sudut pandang yang berbeda dan melatih pemikiran seseorang menuju berpikir kreatif. Berpikir lateral adalah berpikir diluar pola-pola yang sudah umum atau berpikir diluar pendekatan biasanya. Hal ini sejalan dengan pendapat Puspaningtyas (2019) bahwa berpikir lateral merupakan berpikir diluar kebiasaan dan mencari beberapa alternatif dalam penyelesaian masalah. Namun saat ini berpikir lateral peserta didik masih kurang dilatih, hal ini sejalan dengan 
hasil penelitian yang dilakukan oleh Heldayanti, Asfar, Jumrianti, Khusaema and Nurjannah (2019) bahwa perhatian guru dalam mengembangkan kemampuan berpikir lateral peserta didik disekolah masih sangat kurang.

Berdasarkan hasil wawancara peneliti terhadap guru matematika di SMK Karya Nasional Sindangkasih Ciamis, diperoleh informasi bahwa proses berpikir lateral peserta didik belum optimal. Dari pengakuan guru belum optimalnya proses berpikir lateral peserta didik ini terjadi karena selama ini guru belum mencoba memberikan soal ataupun permasalahan yang belum menuntut ataupun mengarahkan peserta didik untuk berpikir lateral. Guru belum pernah memberikan perintah kepada peserta didik untuk menyelesaiakan soal dengan beberapa cara yang berbeda. Maka dari itu, peneliti melakukan studi pendahuluan dan memberikan soal kepada peserta didik yang akan mengarahkan mereka untuk berpikir lateral. Dari hasil studi pendahuluan yang telah dilakukan terhadap peserta didik kelas XI di SMK Karya Nasional Sindangkasih Ciamis diperoleh kesimpulan bahwa memang benar proses berpikir lateral peserta didik belum optimal dan belum memenuhi semua aspek berpikir lateral. Banyak peserta didik yang belum bisa menyelesaikan soal dengan lebih dari satu cara yang berbeda. Selain itu peserta didik pun tidak dapat menemukan ide atau cara penyelesaian yang tidak umum digunakan atau berdasarkan originalitas hasil pemikirannya sendiri. Sehingga perlu dilakukan penelitian lebih lanjut mengenai proses berpikir lateral peserta didik.

Menurut Mukhtasar, Ikhsan and Hajidin (2018) untuk melatih berpikir lateral peserta didik dapat dilakukan dengan memberikan permasalahan yang bersifat terbuka atau bisa disebut dengan open ended. Open ended merupakan suatu masalah yang memiliki lebih dari satu cara penyelesaian dan jawaban benar (Sidabutar, 2016). Dengan memberikan soal open ended kepada peserta didik dapat memberikan kesempatan untuk memecahkan masalah dengan beberapa alternatif penyelesaian yang dimilikinya.

Seperti yang telah dikatakan diawal bahwa proses berpikir setiap peserta didik itu berbeda-beda. Namun pada dasarnya proses berpikir tersebut dipengaruhi oleh beberapa hal. Menurut Ferri (dalam Khair, Subanji \& Muksar, 2018) proses berpikir dipengaruhi oleh pandangan seseorang dalam menghadapi sesuatu, apakah akan membawa hal tersebut kedalam bentuk konkret ataupun kedalam bentuk abstrak. Maka dari itu proses berpikir lateral seseorang juga berbeda-beda, bergantung pada cara berpikir mereka 
masing-masing yang disebut dengan gaya berpikir. Dwirahayu \& Firdausi (2016) menyatakan bahwa proses menyerap dan mengatur informasi setiap peserta didik itu berbeda-beda, mereka memiliki cara masingmasing dan perbedaan ini disebut dengan gaya berpikir. Gaya berpikir merupakan cara yang khas dalam belajar, baik itu berkaitan dengan penerimaan, pengelolaan, sikap terhadap informasi ataupun kebiasaan yang berkaitan dengan lingkungan belajar. Selain itu menurut Hidayat, Ratnaningsih and Santika (2019) gaya berpikir merupakan suatu pola pikir yang membedakan cara peserta didik dalam menerima dan mengolah informasi serta menggunakan informasi yang didapatkan untuk menyelesaikan masalah.

Gregorc (dalam Deporter \& Henarcki, 2016) membagi gaya berpikir menjadi empat kelompok yaitu gaya berpikir Sekuensial Konkret (SK), Sekuensial Abstrak (SA), Acak Konkret (AK), dan Acak Abstrak (AA). Namun dalam penelitian ini hanya berfokus pada gaya berpikir Acak Konkret (AK) dan Acak Abstrak (AA) saja. Gaya berpikir acak konkret memiliki karaktersitik yang eksperimental dan perilaku yang kurang terstruktur, berpikir berdasarkan kenyataan tetapi ingin melakukan pendekatan cobacoba, sering melakukan lompatan intuitif dan bukanlah tipe penurut. Sedangkan gaya berpikir acak abstrak memiliki karakteristik dunia nyata yaitu dunia perasaan dan emosi, tertarik pada nuansa dan sebagian cenderung pada mistisme, menyerap ide-ide, informasi dan kesan serta mengaturnya dengan refleksi. Pada jenjang SMA/Sederajat rendahnya hasil belajar peserta didik terjadi pada beberapa materi, salah satunya dapat dilihat pada materi geometri. Hal ini sejalan dengan pendapat Mukhtasar, et al (2018) yang menyatakan bahwa salah satu hasil belajar peserta didik yang masih rendah dapat dilihat pada materi geometri. Salah satu sub materi pada geometri adalah dimensi tiga. Dimensi tiga merupakan sub materi yang membahas tentang bangun ruang atau benda yang berdimensi tiga (Novita, Prahmana, Indra, Fajri \& Putra, 2018). Objek-objek dalam geometri dimensi tiga bersifat abstrak, sehingga pada saat menghadapi soal peserta didik diharuskan sudah mampu berpikir secara abstrak (Maulana and Pujiastuti, 2020). Namun selama ini peserta didik masih mengalami banyak kesulitan dan kesulitan ini tentu akan berdampak dan menghambat pada pembelajaran geometri selanjutnya, sehingga perlu adanya perhatian dan peningkatan lebih dalam mempelajari materi geometri.

Berdasarkan permasalahan yang telah dijelaskan, perlu adanya penelitian mengenai proses berpikir lateral peserta didik dalam 
menyelesaikan soal open ended pada materi dimensi tiga yang ditinjau dari gaya berpikir acak konkret dan acak abstrak. Hal ini dilakukan dengan tujuan untuk mendeskripsikan proses berpikir lateral peserta didik dalam menyelesaikan soal open ended ditinjau dari gaya berpikir acak konkret dan acak abstrak tersebut.

\section{Metode Penelitian}

Bagian Penelitian yang dilakukan merupakan penelitian kualitatif dengan metode eksploratif dengan tujuan untuk mendeskripsikan proses berpikir lateral peserta didik dalam menyelesaikan soal open ended ditinjau dari gaya berpikir acak konkret dan acak abstrak. Pengungkapan proses berpikir dilakukan oleh peneliti menggunakan metode think aloud. Pelaku yang menjadi subjek dalam penelitian ini merupakan empat peserta didik dari kelas XI di SMK Karya Nasional Sindangkasih Ciamis tahun ajaran 2020/2021 pada semester genap yang telah menempuh materi dimensi tiga. Teknik pemilihan subjek penelitian dilakukan dengan metode eksploratif, yaitu peserta didik diberikan kesempatan secara bergantian untuk menyelesaikan masalah sampai ditemukannya subjek penelitian yang sesuai dengan tujuan penelitian.
Pada penelitian ini terpilih empat orang peserta didik sebagai subjek penelitian. Dari empat subjek penelitian yang terpilih terdapat dua subjek dengan gaya berpikir acak konkret dan dua subjek dengan gaya berpikir acak abstrak. Daftar subjek tersebut dapat dilihat pada tabel 1 di bawah ini.

Tabel 1. Daftar Subjek Penelitian

\begin{tabular}{ccc}
\hline Kode & Kategori Gaya & Simbol \\
Subjek & Berpikir Gregorc & Subjek \\
\hline S14 & Acak Konkret & SAK $_{1}$ \\
S16 & Acak Konkret & SAK $_{2}$ \\
S4 & Acak Abstrak & SAA $_{1}$ \\
S12 & Acak Abstrak & SAA $_{2}$ \\
\hline
\end{tabular}

Subjek penelitian tersebut dipilih berdasarkan data hasil tes soal open ended yang telah dianalisis berdasarkan aspek berpikir lateral dan sudah diberikan angket gaya berpikir Gregorc yang juga sudah dianalisis. Karena subjek-subjek tersebut memenuhi aspek berpikir lateral dan menurut peneliti sudah mewakili karakteristik dari gaya berpikir acak konkret dan acak abstrak yang diinginkan maka subjek-subjek tersebut yang dijadikan sebagai subjek penelitian dan melakukan wawancara. Adapun aspek berpikir lateral dan indikator yang digunakan disajikan dalam tabel 2. 
Tabel 2. Aspek dan Indikator Berpikir Lateral

\begin{tabular}{|c|c|c|}
\hline No & $\begin{array}{l}\text { Aspek Berpikir } \\
\text { Lateral }\end{array}$ & $\begin{array}{c}\text { Indikator Berpikir } \\
\text { Lateral }\end{array}$ \\
\hline 1 & $\begin{array}{lr}\text { Mengetahui } & \text { ide } \\
\text { pokok dari masalah } \\
\text { yang sedang } \\
\text { dihadapi }\end{array}$ & $\begin{array}{l}\text { Mengidentifikasi } \\
\text { unsur-unsur yang } \\
\text { diketahui pada soal. } \\
\text { Ciri-cirinya: } \\
\text { menyatakan apa yang } \\
\text { diketahui dan yang } \\
\text { ditanyakan pada soal. }\end{array}$ \\
\hline 2 & $\begin{array}{l}\text { Mencari cara-cara } \\
\text { alternatif dalam } \\
\text { memandang } \\
\text { permasalahan }\end{array}$ & $\begin{array}{l}\text { Menyelesaikan } \\
\text { permasalahan dengan } \\
\text { lebih dari satu cara. } \\
\text { Ciri-cirinya: dapat } \\
\text { menggunakan lebih } \\
\text { dari satu cara } \\
\text { penyelesaian }\end{array}$ \\
\hline 3 & $\begin{array}{l}\text { Melonggarkan } \\
\text { kendali cara } \\
\text { berpikir yang kaku }\end{array}$ & $\begin{array}{l}\text { Menyelesaikan } \\
\text { permasalahan dengan } \\
\text { cara yang tidak } \\
\text { umum. } \\
\text { Ciri-cirinya: dapat } \\
\text { menyelesaikan } \\
\text { permasalahan dengan } \\
\text { cara yang tidak umum }\end{array}$ \\
\hline 4 & $\begin{array}{l}\text { Menggunakan ide- } \\
\text { ide acak untuk } \\
\text { membangkitkan } \\
\text { ide-ide baru }\end{array}$ & $\begin{array}{l}\text { Menggunakan } \\
\text { langkah-langkah } \\
\text { penyelesaian berbeda } \\
\text { untuk menemukan } \\
\text { jawaban yang benar. } \\
\text { Ciri-cirinya: dapat } \\
\text { memberikan } \\
\text { penjelasan secara } \\
\text { rinci mengenai } \\
\text { langkah penyelesaian } \\
\text { tidak umum yang } \\
\text { telah digunakan }\end{array}$ \\
\hline
\end{tabular}

Sumber : Modifikasi dari Mukhtasar et al. (2018)

Instrumen penelitian yang digunakan dalam penelitian ini yaitu soal open ended, angket gaya berpikir Gregorc dan wawancara. Dalam penelitian ini peneliti mendapat data dengan menggunakan teknik pengumpulan data dari soal tes open ended yang terdiri dari satu buah soal cerita atau kontekstual yang memuat materi dimensi tiga yang telah divalidasi terlebih dahulu oleh dua orang ahli dalam matematika yaitu dosen Pendidikan Matematika, Pascasarjana Universitas Siliwangi dan dosen Pendidikan Matematika Universitas Tanjungpura. Berikut soal open ended yang diberikan kepada peserta didik dalam penelitian ini.

Selesaikan soal di bawah ini!

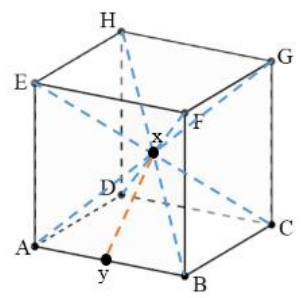

Sebuah kubus ABCD.EFGH mempunyai panjang rusuk $40 \mathrm{~cm}$. Kerangka kubus memuat enam buah limas segi empat yang berimpit, tentukan jarak titik puncak limas (x) dengan tengah-tengah sisi kubus (y), carilah dengan minimal dua cara penyelesaian selain itu kerjakan dengan caramu sendiri disertai dengan alasan menggunakan cara itu!

Selanjutnya angket yang digunakan dalam penelitian adalah angket gaya berpikir Gregorc yang dimodifikasi dari John Le Tellier dan sudah divalidasi ke ahli bahasa yaitu dosen Pendidikan Bahasa Indonesia, Universitas Kuningan. Angket ini terdiri dari 15 soal dan pada setiap soal terdiri dari 4 pernyataan. Peserta didik diberi kesempatan untuk memilih dua pernyataan yang 
menggambarkan dirinya pada setiap soal. Wawancara yang dilakukan merupakan wawancara tidak terstruktur dengan memberikan pertanyaan-pertanyaan yang kondisional sesuai dengan hal yang ingin lebih digali atau lebih diteliti lagi dari jawaban yang telah diberikan oleh masingmasing peserta didik.

Teknis analisis data yang dilakukan yaitu proses analisis data menurut Miles dan Huberman. Proses analisis dimulai dari reduksi data yaitu mengumpulkan hasil dari proses penyelesaian soal open ended dalam materi dimensi tiga, menganalisisnya dan membuat pedoman wawancara dari hasil analisis tersebut, mengumpulkan hasil tes angket gaya berpikir Gregorc dan merangkum hasil tes tersebut, melakukan wawancara terhadap subjek penelitian dan melakukan pengkodean untuk mengetahui alur proses berpikir lateral. Selanjutnya penyajian data yaitu menyajikan data hasil dari proses penyelesaian soal open ended dalam materi dimensi tiga serta hasil wawancara yang telah direkam terhadap subjek penelitian, menyajikan data hasil pemberian angket gaya berpikir, menyajikan alur proses berpikir lateral dari hasil analisis proses pekerjaan subjek penelitian pada materi dimensi tiga dan hasil wawancara untuk masing-masing gaya berpikir. Dan yang terakhir penarikan kesimpulan yang dilakukan dengan mempertimbangkan hasil penyelesaian soal berkaitan dengan proses berpikir lateral, hasil angket gaya berpikir dan hasil wawancara, sehingga diperoleh data yang kredibel berkaitan dengan proses berpikir lateral peserta didik dalam menyelesaikan soal open ended untuk setiap gaya berpikir acak konkret dan acak abstrak.

Dalam penelitian ini dilakukan uji keabsahan data dengan menggunakan uji credibility (kredibilitas) yaitu membandingkan data hasil penelitian dengan data hasil wawancara. Selanjutnya uji transferability yaitu peneliti menguraikan atau mendeskripsikan hasil penelitian secara rinci dan sistematis sesuai dengan penelitian yang diperoleh di lapangan. Selanjutnya uji dependability (dependabilitas) yaitu peneliti berkonsultasi dengan pembimbing untuk mengaudit secara keseluruhan proses di dalam penelitian dan untuk mengurangi kekeliruan-kekeliruan dalam penyajian hasil penelitian. Dan yang terakhir uji konfirmability yaitu peneliti memaparkan data-data secara objektif dengan menunjukkan bukti-bukti hasil penemuan yang diperoleh dilapangan. Kemudian peneliti menjelaskan data tersebut dengan cara menganalisis dan mendeskripsikan hasil temuan dilapangan. 


\section{Hasil dan Pembahasan}

Hasil penelitian dari proses berpikir lateral peserta didik dalam menyelesaikan soal open ended ditinjau dari gaya berpikir acak konkret dan acak abstrak dapat dilihat pada tabel 3 berikut ini.

Tabel 3. Pemenuhan Aspek Berpikir Lateral Subjek

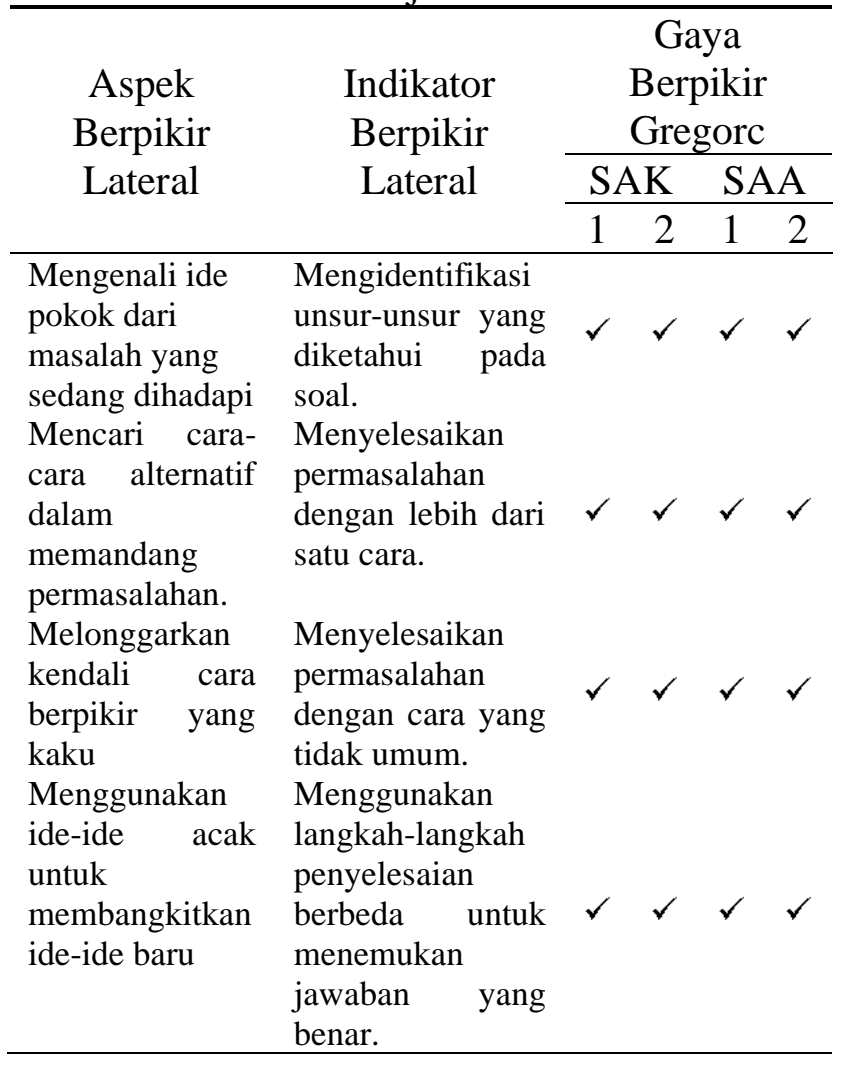

Sebelum membahas proses berpikir setiap subjek penelitian, berikut alur proses berpikir lateral yang dibuat oleh peneliti yang dapat dilihat pada gambar 1 .

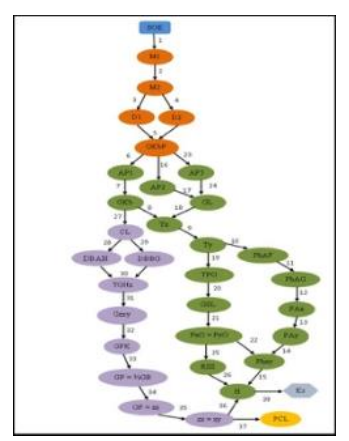

Gambar 1. Alur Proses Berpikir Lateral Peneliti

Keterangan:

Tabel 4. Kode dan Keterangan Gambar Alur Proses Berpikir Lateral

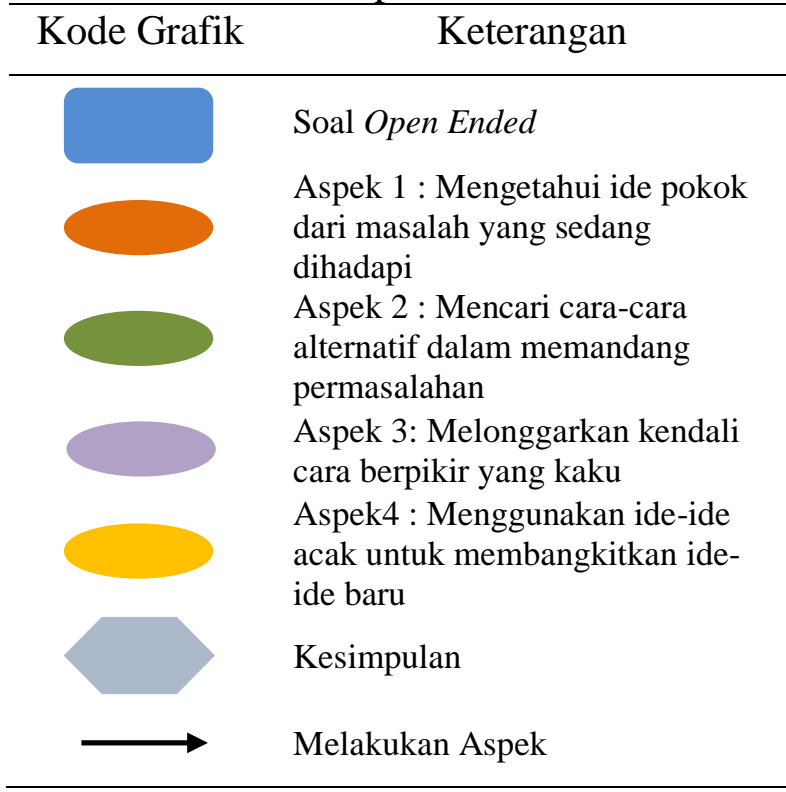

Adapun pembahasan masing-masing proses berpikir peserta didik dalam menyelesaikan soal open ended yang ditinjau dari gaya berpikir acak konkret dan acak abstrak melalui tes tertulis dan wawancara, dapat diuraikan sebagai berikut.

\section{Subjek Acak Konkret (SAK)}

Subjek Acak Konkret $1\left(\mathrm{SAK}_{1}\right)$ dan Subjek Acak Konkret $2\left(\mathrm{SAK}_{2}\right)$ merupakan subjek penelitian yang memiliki gaya 
berpikir acak konkret. Gaya berpikir acak konkret merupakan gaya berpikir yang mempunyai sikap eksperimental dan diiringi dengan perilaku yang kurang terstruktur. (Dwirahayu \& Firdausi, 2016). Hal tersebut terlihat dari hasil penelitian bahwa terdapat penyelesaian soal dari kedua subjek $\left(\mathrm{SAK}_{1}\right.$ dan $\mathrm{SAK}_{2}$ ) yang didapatkan dengan cara bereksperimen atapun mencoba-coba mengikuti apa yang ada dalam pikirannya, sehingga ide yang muncul kurang terstruktur. Namun subjek memiliki dorongan untuk bisa menemukan alternatif penyelesaian dari soal yang dikerjakan. Hal ini sejalan dengan pendapat Mutia (2020) bahwa pemikir acak konkret mempunyai dorongan yang kuat untuk menemukan alternatif dalam mengerjakan sesuatu dengan cara masingmasing.

Pada aspek mengenali ide pokok dari masalah yang sedang dihadapi subjek $\left(\mathrm{SAK}_{1}\right.$ dan $\mathrm{SAK}_{2}$ ) dapat memenuhi indikator mengidentifikasi unsur-unsur yang diketahui pada soal. Meskipun kedua subjek tidak menuliskan apa yang diketahui dan ditanyakan pada soal tersebut, berdasarkan hasil wawancara yang telah dilakukan peneliti, sebenarnya subjek bisa membaca soal dan memahami masalah dengan baik. Hal ini terlihat dari jawaban-jawaban subjek pada saat wawancara dengan peneliti. Ini membuktikan bahwa subjek (SAK 1 dan $\mathrm{SAK}_{2}$ ) memahami masalah pada soal tersebut. Hal ini sejalan dengan pendapat Mutia (2020) yang mengemukakan bahwa gaya berpikir acak konkret dapat menangkap ide dengan cepat tetapi kehilangan beberapa bagian yang pentingnya.

Pada aspek mencari cara-cara alternatif dalam memandang permasalahan subjek ( $\mathrm{SAK}_{1}$ dan $\left.\mathrm{SAK}_{2}\right)$ mampu memenuhi indikator menyelesaikan permasalahan dengan lebih dari dua cara. $\mathrm{SAK}_{1}$ dapat mengerjakan soal sampai akhir dengan dua cara yang berbeda. Sebenarnya subjek menuliskan tiga cara penyelesaian, tetapi dicara kedua subjek tidak menyelesaikan soal tersebut. Dicara kedua $\mathrm{SAK}_{1}$ terlihat sekali menggunakan ide yang acak karena menggunakan rumus segitiga siku-siku sama sisi yang sebenarnya dalam penyelesaian ini jarang sekali digunakan. Sementara itu untuk subjek $\mathrm{SAK}_{2}$ dapat mengerjakan soal dengan tiga cara sampai selesai, tetapi terdapat dua cara yang memiliki kemiripan konsep perbedaanya hanya pada penggunaan garis yang dijadikan patokan untuk dihitung. Kedua subjek mengerjakan dengan cara-cara yang berdeda. Hal ini membuktikan bahwa dalam menyelesaikan masalah subjek gaya berpikir acak konkret bisa menyelesaikan masalah dengan cara yang berbeda. Sesuai 
dengan pendapat Bancong and Subaer (2013) bahwa pemikir acak konkret memiliki alternatif jawaban yang sama dengan menggunakan cara berbeda.

Pada aspek melonggarkan kendali cara berpikir yang kaku kedua subjek $\left(\mathrm{SAK}_{1}\right.$ dan $\mathrm{SAK}_{2}$ ) mampu memenuhi indikator menyelesaikan permasalahan dengan cara yang tidak umum. Terlihat pada lembar jawaban, $\mathrm{SAK}_{1}$ bisa mengerjakan soal sampai akhir dengan dua cara yang berbeda. Sebenarnya $\mathrm{SAK}_{1}$ menuliskan tiga cara penyelesaian, tetapi dicara kedua $\mathrm{SAK}_{1}$ tidak menyelesaikan soal tersebut. Dicara yang ke tiga $\mathrm{SAK}_{1}$ tidak menggunakan konsep phytagoras ataupun rumus. Sementara itu $\mathrm{SAK}_{2}$ mengerjakan soal dengan menuliskan tiga cara, namun dicara ke dua dan ketiga subjek menggunakan cara yang sama perbedaanya hanya terletak dari penggunaan garis yang dijadikan patokan untuk dihitung. Cara kedua dan ketiga yang digunakan $\mathrm{SAK}_{2}$ termasuk ke dalam cara yang tidak umum digunakan dan tidak diajarkan oleh guru artinya subjek menggunakan caranya sendiri untuk menyelesaikan masalah. Sehingga kedua subjek ini $\left(\mathrm{SAK}_{1}\right.$ dan $\left.\mathrm{SAK}_{2}\right)$ menggunakan cara yang hampir sama, subjek mencoba bereksperimen dengan bentuk kubus yang telah dibuat. Selanjutnya subjek menghitung jarak xy dengan menggunakan perhitungan sederhana serta logika yang dimilikinya, cara ini juga dilakukan $\mathrm{SAK}_{2}$ pada proses pengerjaan di cara yang ketiga. Perbedaannya hanya terletak dari penggunaan garis yang dijadikan patokan untuk dihitung. Dari proses eksperimen ini kedua subjek dapat menghasilkan jawaban yang benar. Hal ini sejalan dengan hasil penelitian Ma'rufi (2011) bahwa pemikir acak konkret suka sekali bereksperimen mereka mendasarkan diri pada realitas, tetapi cenderung menggunakan pendekatan cobacoba. Jika dikaitkan dengan matematika yang lebih banyak berhitung, maka dengan pendekatan mencoba-coba bagi peserta didik dengan gaya berpikir acak konkret dapat memberikan kontribusi dalam belajar matematika. Hal lain diungkapkan pada hasil penelitian Mustika, Wulantina, Rahmawati, Sari and Fitrio (2020) bahwa peserta didik dengan gaya berpikir acak konkret mempunyai sikap ingin mencoba atau bereksperimen dalam menyelesaikan masalah.

Pada aspek menggunakan ide-ide acak untuk membangkitkan ide-ide baru kedua subjek $\left(\mathrm{SAK}_{1}\right.$ dan $\left.\mathrm{SAK}_{2}\right)$ mampu memenuhi indikator menggunakan langkah-langkah penyelesaian berbeda untuk menemukan jawaban yang benar. Indikator ini berkaitan dengan indikator yang ketiga karena disini 
subjek harus bisa menjelaskan bagaimana menemukan dan mengerjakan soal menggunakan cara ataupun langkah-langkah penyelesiaan yang berbeda tersebut. Terlihat pada lembar jawaban, $\mathrm{SAK}_{2}$ dapat menuliskan alasan dan menjelaskan bagaimana memperoleh pemikiran tersebut untuk menyelesaikan soal. Hal berbeda terjadi pada $\mathrm{SAK}_{1}$, subjek tidak menuliskan alasan mengapa menggunakan cara penyelesaian tersebut. Namun dari hasil wawancara yang dilakukan, $\mathrm{SAK}_{1}$ mampu menjelaskan bagaimana memperoleh pemikiran tersebut untuk menyelesaikan soal. Meskipun subjek terlihat sekali mengalami kesulitan dalam menjelaskannya. Ini terlihat dari jawaban subjek yang terbata-bata dalam menjawab setiap pertanyaan juga saat subjek menjelaskan prosesnya menemukan ide dan menyelesaikan masalah. Hal ini sejalan dengan pendapat Mutia (2020) bahwa seseorang dengan gaya berpikir acak konkret mengalami kesulitan dalam menjelaskan proses mendapatkan hasil.

Adapun hasil penyelesaian soal oleh $\mathrm{SAK}_{1}$ dan $\mathrm{SAK}_{2}$ dapat dilihat pada gambar 2 dan gambar 3 berikut ini.

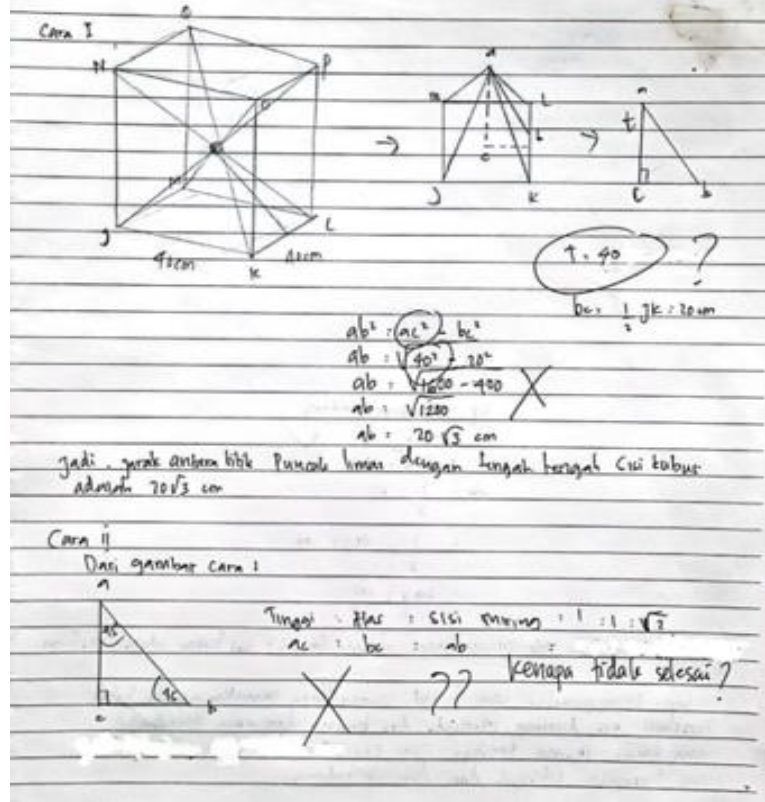

Gambar 2. Hasil Penyelesaian Soal SAK 1

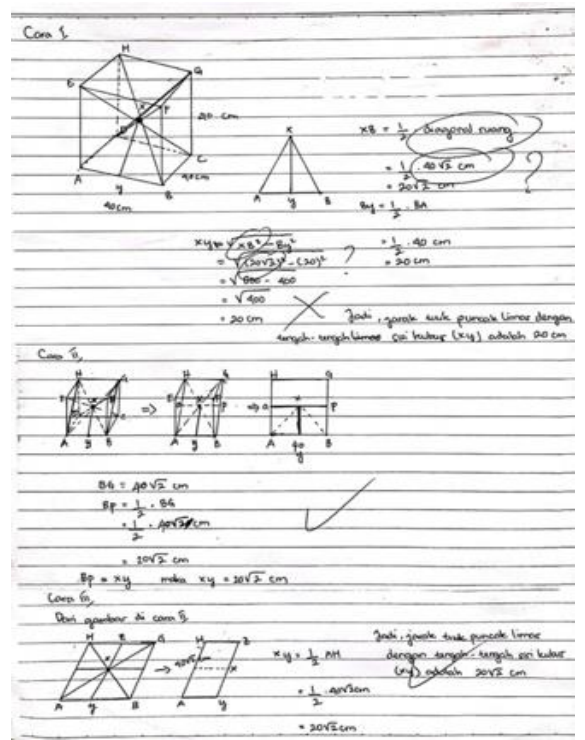

Gambar 3. Hasil Penyelesaian Soal SAK 2 Alur proses berpikir lateral yang dilakukan subjek gaya berpikir acak konkret 1 ( $\left.\mathrm{SAK}_{1}\right)$ dalam menyelesaikan soal open ended pada materi dimensi tiga, dapat dilihat pada gambar 4. 


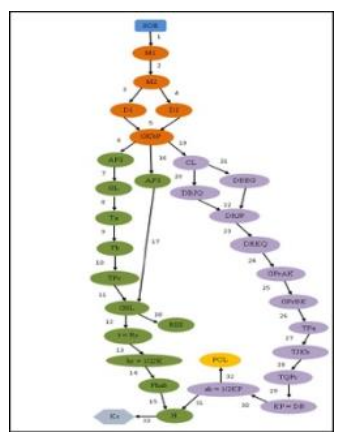

Gambar 4. Alur Proses Berpikir Lateral $\mathrm{SAK}_{1}$

Sementara itu untuk alur proses berpikir lateral yang dilakukan subjek gaya berpikir acak konkret $2\left(\mathrm{SAK}_{2}\right)$ dalam menyelesaikan soal open ended pada materi dimensi tiga, dapat dilihat pada gambar 5.

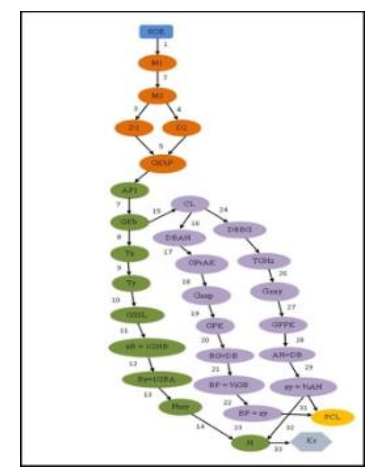

Gambar 5. Alur Proses Berpikir Lateral $\mathrm{SAK}_{2}$

\section{Subjek Sekeuensial Abstrak}

Subjek Acak Abstrak $1\left(\mathrm{SAA}_{1}\right)$ dan Subjek Acak Abstrak 2 (SAA2) merupakan subjek penelitian yang memiliki gaya berpikir acak abstrak. Pemikir acak abstrak menyerap berbagai gagasan, informasi, dan kesan, lalu mengaturnya kembali melalui refleksi. Pemikir acak abstrak dapat mengingat dengan baik jika informasinya dibuat menurut seleranya. Pemikir acak abstrak merasa dibatasi ketika ditempatkan pada lingkungan yang sangat terstruktur (Deporter \& Henarcki, 2016).

Pada aspek mengenali ide pokok dari masalah yang sedang dihadapi subjek $\left(\mathrm{SAA}_{1}\right.$ dan $\mathrm{SAA}_{2}$ ) dapat memenuhi indikator mengidentifikasi unsur-unsur yang diketahui dan ditanyakan pada soal. Meskipun SAA 1 tidak menuliskan apa yang diketahui dan ditanyakan pada soal tersebut, namun berdasarkan hasil wawancara yang telah dilakukan peneliti terhadap subjek, sebenarnya subjek bisa membaca soal dan memahami masalah dengan baik. Hal ini terlihat dari jawaban-jawaban subjek pada saat wawancara dengan peneliti. Subjek bisa langsung menggambarkan dan menjelaskan hal apa saja yang ada dalam soal. Sementara untuk SAA2 menuliskan apa yang diketahui dan ditanyakan dalam soal walaupun kurang lengkap dalam menuliskannya, tetapi dari hasil wawancara subjek mengerti dengan maksud dan perintah dari soal tersebut. Ini membuktikan bahwa subjek $\left(\mathrm{SAK}_{1}\right.$ dan $\mathrm{SAK}_{2}$ ) memahami masalah pada soal tersebut. Hal ini sejalan dengan hasil penelitian Bancong and Subaer (2013) yang mengemukakan bahwa gaya berpikir acak abstrak mengucapkan fakta yang diketahui dan ditanyakan dari permasalahan secara acak 
dan tidak lengkap. selain itu hasil penelitiannya juga mengungkapkan bahwa pemikir acak abstrak tidak menuliskan fakta yang diketahui dan yang ditanyakan.

Pada aspek mencari cara-cara alternatif dalam memandang permasalahan subjek ( $\mathrm{SAA}_{1}$ dan $\mathrm{SAA}_{2}$ ) mampu memenuhi indikator menyelesaikan permasalahan dengan lebih dari satu cara. Hal ini sejalan dengan pendapat Bancong and Subaer (2013) bahwa pemikir acak abstrak memiliki dua cara dalam menyelesaikan masalah. Bahkan dalam penelitian ini pemikir acak abstrak memiliki lebih dari dua cara penyelesaian masalah.

Pada aspek melonggarkan kendali cara berpikir yang kaku kedua subjek $\left(\mathrm{SAA}_{1}\right.$ dan $\mathrm{SAA}_{2}$ ) mampu memenuhi indikator menyelesaikan permasalahan dengan cara yang tidak umum. Terlihat pada lembar jawaban subjek (SAA1 dan $\left.\mathrm{SAA}_{2}\right)$ bisa mengerjakan soal tersebut dengan tiga cara yang berbeda, dan cara yang ke tiga ini kedua subjek tidak menggunakan konsep phytagoras, rumus ataupun konsep yang lainnya. Subjek hanya menggambarkan objek dengan asumsi tertentu yang dimilikinya dengan cara menambahkan ataupun membuat penggambaran lain dari bentuk kubus yang sebelumnya diketahui. Hal ini sejalan dengan hasil penelitian Bancong and Subaer (2013) bahwa pemikir acak abstrak menggambarkan objek dengan beberapa asumsi tertentu sehingga didapatkan hasil dari soal yang dikerjakan.

Pada aspek menggunakan ide-ide acak untuk membangkitkan ide-ide baru kedua subjek ( $\mathrm{SAA}_{1}$ dan $\left.\mathrm{SAA}_{2}\right)$ mampu memenuhi indikator menggunakan langkah-langkah penyelesaian berbeda untuk menemukan jawaban yang benar. Indikator ini berkaitan dengan indikator yang ketiga karena disini subjek harus bisa menjelaskan bagaimana menemukan dan mengerjakan soal menggunakan cara ataupun langkah-langkah penyelesiaan yang berbeda tersebut. Terlihat pada lembar jawaban, kedua subjek dapat menjelaskan dan mengungkapkan alasannya mengapa menggunakan cara tersebut untuk menyelesaikan soal. Hal ini sejalan dengan hasil penelitian Bancong and Subaer (2013) bahwa pemikir acak abstrak mempunyai asumsi atau cara lain untuk memperoleh hasil yang sama dan dikerjakan.

Adapun hasil penyelesaian soal oleh $\mathrm{SAA}_{1}$ dan $\mathrm{SAA}_{2}$ dapat dilihat pada gambar 6 dan gambar 7 berikut ini. 


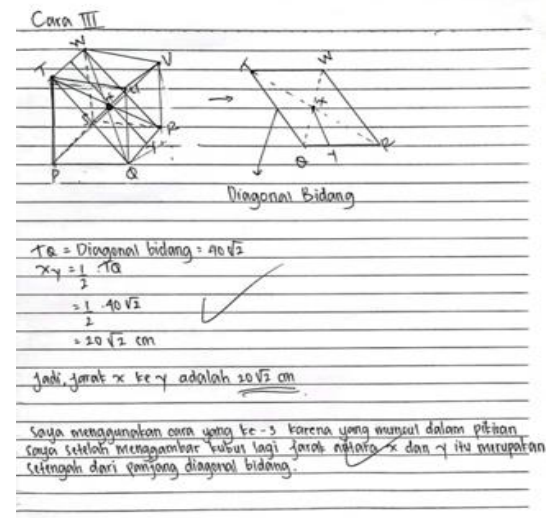

Gambar 6. Hasil Penyelesaian Soal SAA 1

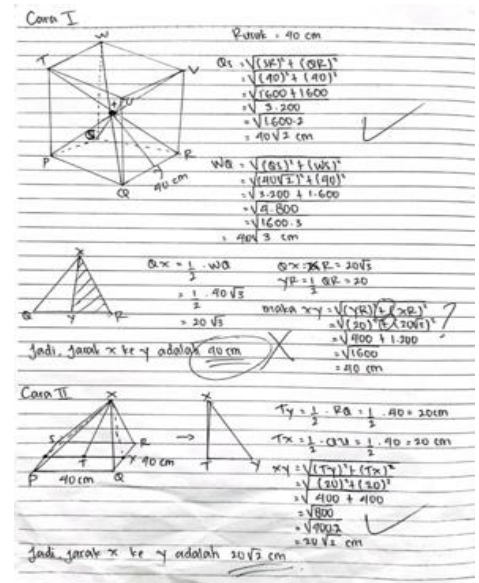

Gambar 7. Hasil Penyelesaian Soal SAA2

Alur proses berpikir lateral yang dilakukan subjek gaya berpikir acak abstrak 1 $\left(\mathrm{SAA}_{1}\right)$ dalam menyelesaikan soal open ended pada materi dimensi tiga, dapat dilihat pada gambar 8 .

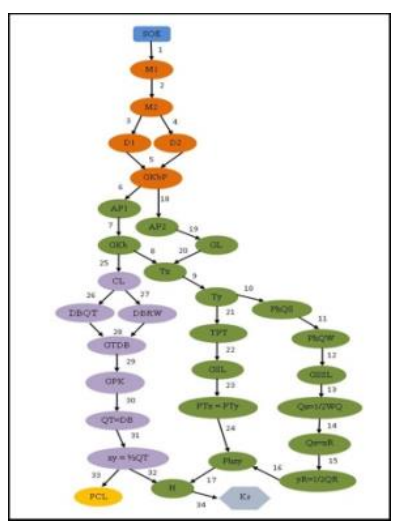

Gambar 8. Alur Proses Berpikir SAA 1

Sementara itu untuk alur proses berpikir lateral yang dilakukan subjek gaya berpikir acak abstrak 2 (SAA2) dalam menyelesaikan soal open ended pada materi dimensi tiga, dapat dilihat pada gambar 9 .

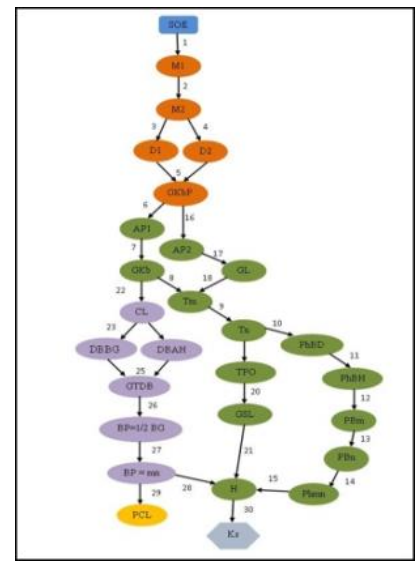

Gambar 9. Alur Proses Berpikir SAA2

\section{Kesimpulan}

Berdasarkan hasil penelitian dan pembahasan proses berpikir lateral peserta didik dalam menyelesaikan soal open ended ditinjau dari gaya berpikir acak konkret dan acak abstrak, maka kesimpulannya sebagai berikut: Proses berpikir lateral peserta didik 
dengan gaya berpikir Acak Konkret (AK) 1)

Pada aspek mengetahui ide pokok dari masalah yang sedang dihadapi peserta didik mampu memahami masalah. 2) Pada aspek mencari cara-cara alternatif dalam memandang permasalahan peserta didik mampu menyelesaikan permasalahan dengan lebih dari satu cara. 3) Pada aspek melonggarkan kendali cara berpikir yang kaku peserta didik mampu menyelesaikan permasalahan dengan cara yang tidak umum.

4) Pada aspek menggunakan ide-ide acak untuk membangkitkan ide-ide baru peserta didik mampu menggunakan langkah-langkah penyelesaian berbeda untuk menemukan jawaban yang benar.

Proses berpikir lateral peserta didik dengan gaya berpikir Acak Abstrak (AA) 1) Pada aspek mengetahui ide pokok dari masalah yang sedang dihadapi peserta didik mampu memahami masalah 2) Pada aspek mencari cara-cara alternatif dalam memandang permasalahan peserta didik mampu menyelesaikan permasalahan dengan lebih dari satu cara. 3) Pada aspek melonggarkan kendali cara berpikir yang kaku peserta didik mampu menyelesaikan permasalahan dengan cara yang tidak umum. 4) Pada aspek menggunakan ide-ide acak untuk membangkitkan ide-ide baru peserta didik mampu menggunakan langkah-langkah penyelesaian berbeda untuk menemukan jawaban yang benar.

Berdasarkan kesimpulan di atas, maka saran dari peneliti yaitu sebagai berikut: 1) Peserta didik dengan gaya bepikir Acak Konkret (AK) harus lebih bisa terstruktur dalam mengerjakan permasalahan. Hal ini dilakukan agar hasil penyelesaian masalah peserta didik tersebut bisa tersusun dengan baik dan benar. Guru bisa mengarahkan peserta didik untuk selalu menuliskan apa yang diketahui dna ditanyakan dalam soal tersebut. 2) Peserta didik dengan gaya bepikir Acak Abstrak (AA) harus dilatih untuk bisa mengerjakan sesuatu dalam ruang lingkup yang terstruktur. Guru bisa memberikan arahan agar peserta didik bisa mengelola informasi dari permasalahan meskipun tanpa personifikasi ataupun pengandaian lebih awal. 3) Secara umum proses berpikir lateral peserta didik perlu dilatih oleh guru dengan cara memberikan soal-soal yang memiliki berbagai macam penyelesaian sehingga peserta didik terlatih untuk memandang suatu permasalahan lebih dari satu sudut pandang sehingga didapatkan cara penyelesaian masalah yang beragam.

\section{Ucapan Terimakasih}

Saya ucapkan terima kasih kepada semua pihak yang telah membantu saya dalam proses penelitian ini. Terutama untuk 
keluarga dan teman sejawat yang selalu mendukung.

\section{Pustaka}

Bancong, S. (2013). Profil penalaran logis berdasarkan gaya berpikir dalam memecahkan masalah fisika peserta didik. Jurnal Pendidikan IPA Indonesia 2(2) 195-202.

Deporter, B \& Henarcki, M. (2016). Quantum learning. Membiasakan belajar nyaman dan menyenangkan. (A. Abdurrahman, Trans.). Bandung, Indonesia: Kaifa

Dwirahayu, G., \& Firdausi, F. (2016). Pengaruh gaya berpikir terhadap kemampuan koneksi matematis mahasiswa. JPPM (Jurnal Penelitian dan Pembelajaran Matematika), 9(2).

Heldayanti, H., Asfar, A. I. T., Asfar, A. I. A., Jumrianti, J., Khusaema, L., \& Nurjannah, S. (2019, December). Penerapan model pembelajaran poget menggunakan media audiovisual dalam membangun kemampuan berpikir lateral siswa. In Seminar Nasional Hasil Penelitian \& Pengabdian Kepada Masyarakat (SNP2M) (pp. 325-330).

Hidayat, E., Ratnaningsih, N., \& Santika, S. (2019, November). Pemetaan Gaya Berpikir Peserta Didik Berdasarkan Kemampuan Koneksi Matematis.
In Prosiding Seminar Nasional \& Call For Papers.

Khair, M. S. D., Subanji, S., \& Muksar, M. (2018). Kesalahan Konsep dan Prosedur Siswa dalam Menyelesaikan Soal Persamaan Ditinjau dari Gaya Berpikir. Jurnal Pendidikan: Teori, Penelitian, dan Pengembangan, 3(5), 620-633.

Maulana, F., \& Pujiastuti, H. (2020). Analisis Kesalahan Siswa Smadalam Menjawab Soal Dimensi Tiga Berdasarkan Teori Newman. MAJU: Jurnal Ilmiah Pendidikan Matematika, 7(2).

Muflihah, I. S., Ratnaningsih, N., \& Apiati, V. (2019). Analisis kemampuan koneksi matematis ditinjau dari gaya berpikir peserta didik. Journal of Authentic Research on Mathematics Education (JARME), 1(1).

Mukhtasar, Ikhsan, M., Hajidin. (2018). Proses berpikir lateral siswa madrasah aliyah dalam menyelesaikan masalah geometri melalui pendekatan openended. Jurnal Penelitian Pendidikan Agama dan Keagamaan, 16 (3), 331 346.

Muliawati, N. E. (2017). Proses berpikir lateral siswa dalam memecahkan masalah berdasarkan gaya kognitif dan gender. JP2M (Jurnal Pendidikan dan 
Pembelajaran Matematika), 2(1), 5568.

Mutia, Z. A. (2020). Analisis Jenis Gaya Berpikir Yang Dominan Dalam Mempengaruhi Miskonsepsi Peserta Didik Analisis Jenis Gaya Berpikir Yang Dominan Dalam Mempengaruhi Miskonsepsi Peserta Didik Pada Materi Kalor Dan Perpindahan Kalor Di MAS Darul Ulum (Doctoral dissertation, UIN Ar-Raniry Banda Aceh).

Novita, R., Prahmana, R. C. I., Fajri, N., \& Putra, M. (2018). Penyebab kesulitan belajar geometri dimensi tiga. Jurnal Riset Pendidikan Matematika, 5(1), 1829.

Nurjanah, S., Hidayanto, E., \& Rahardjo, S. (2019). Proses berpikir siswa berkecerdasan matematis logis dalam menyelesaikan masalah matematis "ill structured problems. Jurnal Pendidikan: Teori, Penelitian, dan Pengembangan, 4(11), 1441-1447.

Puspaningtyas, N. D. (2019). Proses berpikir lateral siswa sd dalam menyelesaikan masalah matematika open-ended ditinjau dari perbedaan gaya belajar. MAJAMATH: Jurnal Matematika dan Pendidikan Matematika, 2(2), 80-86.
Sidabutar, N. D. (2016). Profil pemecahan masalah matematika open-ended dengan tahap creative problem solving (CPS) ditinjau dari kemampuan matematika siswa. MATHEdunesa, 5(1).

Tobias, C. U. (2009). Cara mereka belajar. Jakarta, Indonesia: Pionir

Wardhani, W. A., Subanji., Dwiyana. (2016).

Proses berpikir siswa berdasarkan kerangka kerja Manson. Jurnal Pendidikan: Teori, Penelitian, dan Pengembangan, 1(3). 297-313.

Wendayani, W., Ratnaningsih, N., \& Muhtadi, D. (2019). Implementasi Model Pembelajaran Osborn untuk Menggali Kemampuan Berpikir Lateral Matematik Ditinjau dari Gaya Belajar Peserta Didik. Journal of Authentic Research on Mathematics Education (JARME), 1(2), 112-123.

Zakir，M. (2015). Description of Logical Reasoning in Solving Mathematics Problems Based on Students' Thinking Style of Students at SMPN 2 Pinrang. Jurnal Daya Matematis, 3(2), 152-165. 
